\title{
Meetings
}

\author{
REPORTS ON RECENT MEETINGS
}

24th I.G.C., Montreal, Quebec, Canada, August 21 to $31,1972$.

This meeting is on the records as the largest scientific gathering ever held in Canada and was commemorated by a special issue of postal stamps. Many reviews will be written on this exceptionally well organized congress and the Congress executive and conmittees must be complimented for their efforts. The language of the Congress was both French and English and commonly the speakers were bilingual with numerous references given for a second language which you may interpret as either English or French.

The opening cexemonies were accompanied to the tunes of the RCMP band and as the curtain raised with the strains of 'O CANADA', most Canadians were particularly stirred. At the Plenary session on opening day, three solid addresses were given on the subject of the environment and quality of life. One message brought home referred to our depleting resources throughout the world and that, although we had sufficient minerals in the earth's crust and soil, it would become more difficult with each year to win them. We are then faced with an all-consuming energy situation and may have to return to the physicists to lead us out of the problems that lie ahead in our quest for energy and power.

Technical sessions were carried on through the day beginning at 8:30 a.m. and ending at 2 p.m. when time was allowed for visiting and shopping. However; a number of important symposia were held from $2: 15 \mathrm{p} . \mathrm{m}$. to $5 \mathrm{p} . \mathrm{m}$. and this generally took up the remainder of the day. The meeting was huge and was held in four different hotels with approximately fifteen sessions running concurrently. This made it difficult to maneuver and all of us who were pressed to move from building to building soon rejoiced at seeing the end of the day's session.

One of the symposia that we attended was a wide-ranging account of the deep sea drilling project; its scientific program, results and new thrusts. Another exceptional event was an afternoon devoted to the astronaut program. Two of the astronauts, the space program director and scientific consultants working on the moon rocks and structure gave very fine addresses. It was an exciting adventure to hear these men discuss the moon topography and its features and some of the more remarkable experiments carried out.

On the social side, reunions ranging from individual classmates and field workers to full scale university gatherings with the usual libations and celebrations were held. Montreal needs no explanation as there is something there for everyone and except for the humidity, the weather was generally kind and warm. The Montreal Expos were generous in winning their ball game for the Congress, while the Congress itself was generous to its delegates at two or three icebreaker parties. On the whole, the organization was superb. Programs were planned for the scientists, their families and a mini congress was provided for the children interested in science. The hotel accommodations were jammed to the rafters and it was necessary to revert to smuggling in elements of the family in order to provide a roof over their head. Transportation around Montreal was simple and fairly reasonable and centre Town still remains the chief attraction of the city.

Another excellent feature was the Georama held at Place Bonaventure. This was the exhibits hall and, the booth in which the Bedford Institute display was lodged, was called Atlantic Canada and featured, among other things, the model of the CSS HUDSON and some of the display material which was shown at the Halifax International Airport. Generally the booths were well managed, very tidy, and with careful attention paid to a neat manner in exhibiting display material. No crowding existed in the corridors, and arple and varied content satisfied the visitors. This aspect of the Congress was truly handled well.

Outside of Montreal the field trips were generally successful, particularly the excursion into the Arctic Islands. Approximately 70 field trips were made including some in the Atlantic Provinces, which include visits to local institutions.

Now that we have lived through this massive conference it is worthwhile remarking that it was a good one but we thought perhaps too large. Leviathan is perhaps the smallest word that I can use to describe it, and then a general feeling that such congresses should be smaller and perhaps could be managed with less administration. The organizing committee and Executive is to be complimented on their fine work. Indeed, 500 people were required almost all hours for the past several months in order to make this the success it was. All papers submitted were published in advance of the Congress and it was rewarding to see the volumes on the table for sale and distribution. The next Congress is in Australia in 1976 and it is unlikely that we shall have another one in Canada in our time. For this reason, most Canadian scientists connected with the Congress put their best efforts into the project and made it the success it was.

B.R. Pelletier, Atlantic Geoscience Centre, Bedford Institute of Oceanography, Dartmouth, N.S. 
22nd International Geographical Congress - the Ca 5 Coastal Commission Meeting, Halifax, Nova Scotia, August 2 to 9,1972 .

This meeting was organized locally under Dr. S.B. McCann of McMaster University, Hamilton, ontario and consisted of field excursions and a technical session.

\section{List of Papers}

Shoreline Erosion on the Barron Delta, North Queensland - E.C.F. Bird, Department of Geography, University of Melbourne, Parkville, Victoria, Australia.

The Barrier Islands of Kouchibouguac Bay, New Brunswick - E.A. Bryant, Department of Geography, McMaster University, Hamilton, Ontario.

Caracteristiques des Schorres des Regions Froides - J-C. Dionne, Ministerre de l'Environement, C.P. 3800 , Sainte-Foy, Quebéc 10, Quebéc.

Morphological and Textural Characteristics of Longshore Bars and Troughs, Kouchibouguac Bay, New Brunswick - B. Greenwood and R.D. Arnott, Department of Geography, Scarborough College, University of Toronto, Ontario.

Un banc Corallien Oriente: Reef Island aux iles banks, Nouvelles-Hebrides - A.J. Builcher, Faculté des Lettres, B.P. $860,29 \mathrm{~N}$ Brest, France.

Zonal Studies of the Coast of the Maritime Region of Canada - E.H. Owens, Atlantic Geoscience Centre, Bedford Institute of Oceanography, Dartmouth, Nova Scotia.

Some Aspects of the Importance of Tidal Range in Coastal Studies - C. Kidson, Department of Geography, University College of Wales, Llandinam Bldg., Penglais, Aberystwyth, Cards, Wales.

Characteristics of Arctic Beaches - S.B. McCann, Department of Geography, McMaster University, Hamilton, Ontario.

Morphodynamics of the Nile Delta - Wm. G. McIntyre, Coastal Studies Institute, Louisiana State University, Baton Rouge, Louisiana.

The Effect of Typhoons on Beaches in Hong Kong - C.L. So, Department of Geography and Geology, University of Hong Kong, Pokfulam Road, Hong Kong.

Accelerating Crisis in Beach Erosion - W.F. Tanner and F. Stapor, Geology Department, Florida State University, Tallahassee, Florida.

A Classification of Coastal Classifications - H. Valentin, Institut fur Geographie, Technische Universitat Berlin, Strasse des 17 juni 135, D-1 Berlin 12, Federal Rep. of Germany.

Post-glacial Emergence of the Bay of Fundy Coast - J.E. Welsted, Department of Geography, Brandon University, Brandon, Manitoba.

Atlantic Geoscience Society, Halifax, Nova Scotia, September 27, 1972.

At a regular meeting of the Atlantic Geoscience Society held at Dalhousie University, Halifax, Nova Scotia on September 27, 1972, the guest speaker was Dr. John Dewey of State University of New York, Albany, New York. His theme was based on an application of ocean-floor spreading to mountain ranges.

FORTHCOMING MEETINGS

G.S.A. Penrose Conference on Structure of Continental Margins, Warrenton, Virginia, December 10 to 15,1972 .

The Geological Society of America is planning its Penrose Conference for 1972 on the geological history and structure of continental margins. This meeting will be multi-disciplinary in scope and its attendance limited to 75 participants. It is convened by Creighton $A$. Burke and Charles L. Drake, and for information please write: C.A. Drake, Department of Earth Science, Dartmouth College, Hannover, New Hampshire 03755, U.S.A., or C.A. Burke, Mobil Oil Corporation, 221 Nassau Street, Princeton, New Jersey 08540, U.S.A.

Joint G.A.C., A.S.P.G. and M.A.C. Annual Meeting, University of Regina, Saskatchewa, May 23 to $23,1973$.

Annual meetings of the Geological Association of Canada, the Alberta Society of Petroleum Geologists, and the Mineralogical Association of Canada. Three concurrent programs will be run: Colloquium on the Cretaceous System of the Western Interior of North America sponsored by the G.A.C.; Symposium on the Geology of the Canadian Arctic sponsored by the A.S.P.G. and the G.A.C. (held jointly with the 5th Annual Canadian Conference on Research in Tectonics); and a Conference run by the Mineralogical Association of Canada, University of Saskatchewan, Saskatoon. For further information write to: Dr. W.O. Kupsch, Institute for Northern Studies, University of Saskatchewan, Saskatoon, Canada. 